\title{
Üniversite Öğrencilerinin Kültürel Miras Farkındalığını Değerlendirmede Önem-Performans Analizinin (ÖPA) Kullanımı
}

\author{
Dr. Öğr. Üyesi Tolga GÖK \\ Kırgızistan-Türkiye Manas Üniversitesi, Turizm ve Otelcilik Yüksekokulu \\ Selçuk Üniversitesi, Silifke-Taşucu Meslek Yüksekokulu \\ tolga.gok@manas.edu.kg \\ https://orcid.org/0000-0002-9252-9504 \\ DOI: https://doi.org/10.37847/tdtad.838415 \\ Makale Türü: Araşttrma Makalesi \\ Makale Gönderim Tarihi: 09.12.2020 \\ Makale Kabul Tarihi: 26.12.2020
}

\section{Özet}

Bu çalışmanın amacı, Kırgızistan'ın UNESCO tarafından belirlenen kültürel miraslarına ilişkin üniversite öğrencilerinin farkındalığını değerlendirmektir. Geliştirilen anket yardımıyla, Kırgızistan-Türkiye Manas Üniversitesi’nde (KTMÜ) öğrenim gören 408 öğrencinin Kırgızistan'1n kültürel miraslarına ilişkin bilinirlik ve deneyimleme algıları tespit edilmiştir. Çalışmanın amacı doğrultusunda, Martilla ve James (1977) tarafindan geliştirilen Önem-Performans Matrisi uyarlanarak Bilinirlik-Deneyimleme Matrisine dönüştürülmüştür. Geliştirilen matris yardımıyla Kültürel Miras Bilinirliği ve Deneyimleme düzeyleri analiz edilmiştir. Verilerin analizinde geliştirilen Bilinirlik-Deneyimleme Analizi (BDA) ve Eşleştirilmiş Örneklem T-testi kullanılmıştır. Bilinirlik-Deneyimleme Analizi (BDA) sayesinde her bir kültürel miras unsurunun matriste yer alan konumuna göre farkındalık düzeyi ortaya konmuştur. Kırgızistan'ın kültürel miraslarının farkındalığına ilişkin yapılan Bilinirlik-Deneyimleme Analizi (BDA) sonuçlarına göre, "Nevruz" ve "Manas Destanı"nın farkındalık düzeyleri oldukça yüksektir ve mevcut düzey korunmalıdır. "Kökbörü-geleneksel at oyunu", "Kutsal Süleyman Dağı" ve "Manasçılar" kısmi farkındalık düzeyine sahiptir ve deneyimleme anlamında geliştirilmesi gerekmektedir. "İpek Yolu Ulaşım Ağı", "İnce Ekmek Yapma ve Paylaşma Kültürü” ve "Atışma Doğaçlama Sanatı" kısmi farkındalık düzeyine sahiptir ve bilinirlik düzeylerinin artırılması gerekmektedir. "Batı Tanrı Dağları (TienShan)", "Boz Üy Yapımı" ve "Ala Kıyız ve Shyrdak, Geleneksel Kırgız Keçe Halı Sanatı"nın farkındalık düzeyleri düşüktür ve hem bilinirlik hem de deneyimleme açısından gelecek kuşaklar için geliştirilmelidir. Ayrıca kültürel miras unsurlarının bilinirlik ve deneyimleme düzeylerine ilişkin aritmetik ortalama değerleri eşleştirilmiş örneklem t-testi (Paired-sample t-test) ile karşılaştırılmıştır. Analiz sonucunda, tüm kültürel miras unsurlarının bilinirlik ve deneyimleme düzeyleri arasında anlamlı farklılık olduğu görülmüştür. Bu bağlamda, kültürel mirasların farkındalık düzeylerinin genel olarak orta ve düşük düzeyde olması nedeniyle geliştirilmesine yönelik çalışmalar teşvik edilmelidir. Bu çalışma, kültürel miras farkındalığının değerlendirilmesi açısından Önem-Performans Analizi tekniğinin uyarlandığı ilk araştırma olma niteliğini taşımaktadır.

Anahtar Kelimeler: Kültürel Miras Farkındalığı, Önem-Performans Analizi, Bilinirlik, Deneyimleme, Kırgızistan 


\title{
The Use of Importance-Performance Analysis (IPA) in Evaluating University Students' Awareness of Cultural Heritage
}

\begin{abstract}
The purpose of this study is to evaluate the awareness of university students regarding the cultural heritages of Kyrgyzstan determined by UNESCO. With the help of the developed survey, the perceptions of familiarity and experience on Kyrgyzstan's cultural heritages of 408 students studying at Kyrgyz-Turkish Manas University (KTMU) were identified. In accordance with the purpose of the study, the Importance-Performance Matrix developed by Martilla and James (1977) was adapted into the Familiarity-Experience Matrix. Cultural heritage familiarity and experience levels were analyzed with the help of the developed matrix. Familiarity-Experience Analysis (FEA) and Paired-sample t-test were used for data analysis. Thanks to the Familiarity-Experience Analysis (FEA), the levels of awareness were revealed according to the position of each cultural heritage in the matrix. According to the results of the Familiarity-Experience Analysis (FEA) made on the awareness of the cultural heritage of Kyrgyzstan, the awareness levels of "Nowruz" and "Kyrgyz epic trilogy: Manas, Semetey, Seytek" are quite high and their current levels should be preserved. "Kok boru-traditional horse game", "Sulaiman-Too Sacred Mountain" and "Art of Akyns, Kyrgyz epic tellers" have a partial awareness level and need to be developed in terms of experience. "Silk Roads: The Routes Network of Chang'an-Tianshan Corridor", "Flatbread making and sharing culture" and "Aitysh/Aitys, the art of improvisation" have a partial level of awareness and familiarity levels need to be increased. The awareness levels of "Western Tien-Shan", "BozuyTurkic nomadic dwellings)" and "Ala-kiyiz and Shyrdak, the art of Kyrgyz traditional felt carpets" are low and should be developed for future generations in terms of both familiarity and experience. In addition, the arithmetic mean values of the familiarity and experience levels of cultural heritage elements were compared with the paired-sample t-test. As a result of the analysis, it was seen that there is a significant difference between the familiarity and experience levels of all cultural heritage elements. In this context, efforts to improve the awareness levels of cultural heritage should be encouraged due to their medium and low levels generally. This study is the first research in which the importance-performance analysis technique has been adapted to evaluate cultural heritage awareness.
\end{abstract}

Keywords: Cultural Heritage Awareness, Importance-Performance Analysis, Familiarity, Experience, Kyrgyzstan

\section{GíRiș}

Kültür, bir toplumun millet olarak tanımlanabilmesi için zorunlu olan, toplum tarafindan tarihsel süreç içerisinde oluşturulan ve kuşaktan kuşağa aktarılan genel kabul görmüş maddi/manevi değerlerin tamamıdır (Öztürk ve Caber, 2017). Toplumun yüzyıllar içerisinde kabul ettiği ve yaşattığı bu maddi/manevi değerler kültürel mirasın kaynağını oluşturmaktadır. Kültür aynı zamanda bir toplumu başka bir toplumdan ayırt edici olan ve bir milletin varlığının ve bütünlügünün kaynaklarından birisidir. $\mathrm{Bu}$ nedenle kültürün yaşatılması ve devamlılığının sağlanması açısından büyük önem taşımaktadır.

Son yıllarda özellikle dış turizmde farklı kültürleri merak duygusu turistlerin tercihlerinde önemli rol oynamaya başlamıştır. Turistler tarafından farklı kültürleri merak etme, öğrenme ve deneyimleme isteği turistlerin destinasyon seçimini etkilemektedir. Kültür turizmi çerçevesinde tarihi yerlerin, arkeolojik alanların ziyaret edilmesi, otantik yaşamların/yaşam alanlarının ve mutfakların deneyimlenmek istenmesi, festivallere katılma isteği, geleneksel dans ve törenlerin 
deneyimlenmek istenmesi turistlerin bir kısmının tercihlerini kültür turizmine yöneltmiştir (Besculides, Lee ve MacCormick, 2002; Okuyucu ve Somuncu, 2012).

Turistlerin kültür turizmine yönelmesi, turistik destinasyonlardaki kültürel kaynakların bilinirliğini ve değerinin yerel halk tarafindan anlaşılmasını sağlamıştır. Bu alanda yapılan çalışmalar kültür turizminin yerel halka, onların kültürlerine ve turistlere de yararlar sağladığını göstermektedir (Besculides vd., 2002). Turizmde önemli bir alternatif olan kültür turizmi, ülkeler için gelir sağlayıcı etkisinin yanında kültürel değerlerin korunması (Ablak, Dikmenli ve Çetin, 2014) ve gelecek nesillere de aktarılması açısından üzerinde durulması gereken bir turizm kaynağıdır. Bir ülke için, kültürel değerlerin korunması ve gelecek nesillere aktarılması doğrultusunda genç nesillerin kültürel değerler konusunda bilinçlendirilmesi ve kültürel varlıklara gereken önemin verilmesi oldukça önemlidir.

UNESCO kültürel miras listesinde yer alan kültürel değerler turistler için bir cazibe merkezi olmaktadır (Breakey, 2012). Aynı zamanda bu listede yer alan kültürel miras eserleri gelecek nesiller için korunmaya çalışılmakta (Santa-Cruz ve Guzman, 2017) ve önemli bir karar unsuru olarak ortaya çıkmaktadır (Correia, Kozak ve Ferradeira, 2013). Dünya kültürel miras listesinde yer alan bu eserler, turistlerin destinasyon seçiminde önemli bir unsur olmaktadır. Ancak, kültürel miras eserlerinin turistler tarafından ilgi çekici bulunması bu eserlerin hayatta kalma sürecine zarar verebilir. Bu nedenle turistik çekiciliğe sahip olan kültürel miras eserlerini korumak, devamlılığını sağlamak ve turizmde çekiciliğini devam ettirmek için gençlerde kültürel miras farkındalığ oluşturmak büyük önem taşımaktadır.

Bu çalışmada Kırgızistan'ın sahip olduğu kültürel miras unsurlarına yönelik Kırgızistan-Türkiye Manas Üniversitesi'nde öğrenim gören öğrencilerin kültürel miras farkındalıkları belirlenmeye çalışılmıştır. $\mathrm{Bu}$ amaçla Önem-Performans Analizi (IPA) kullanılarak geliştirilen BilinirlikDeneyimleme Analizi (BDA) ile Kırgızistan'ın her bir kültürel mirasına ilişkin farkındalıklarının ortaya konması hedeflenmiştir.

\section{KAVRAMSAL ÇERÇEVE}

\section{Kültür ve Turizm}

Kültür, toplumu oluşturan bireylerin günlük yaşamında yer tutan beslenme, giyinme, folklor, müzik, tarih, inanç vb. özel uygulamalarla gerçekleşen (Tekeli, 2010) faaliyetler, örf ve adetlerden oluşmaktadır. Kültür, nesiller tarafından oluşturulan yazılı, sözlü veya sözsüz gelenekler, geleneksel üretim, sosyal yaşamda kabul edilmiş uygulamalar, ritüeller, festivaller sonucu ortaya çıkan maddi ve manevi unsurlardır (Jokilehto, 2005; Vecco, 2010). Avcıkurt'a (2007) göre ise kültür; "insanlığın doğa ile olan mücadelesindeki tüm maddi ve manevi kazanımlardır".

Sosyolojik açıdan ise kültür "etkileşimlere yön veren senaryo ve rollerin işleyişinin daha iyi anlaşılmasına yardım eden ve bir toplumu diğer toplumdan ayırt eden bir kavram" olarak tanımlanmaktadır (Kocadaş, 2005, s. 3). Kültürün somut ve somut olmayan (maddi ve manevi) iki boyutu vardır. İnsan elinden çıkmış olan bütün araç, malzeme ve tüm kullanım eşyaları kültürün somut (maddi) boyutunu; toplumlar tarafindan kabul görmüş olan gelenek, görenek, örf, adet, kurallar ve ritüeller ise kültürün soyut (manevi) boyutunu oluşturmaktadır.

Kültür, toplumların geçmişi, bugünü ve geleceği hakkında bilgi veren, aynı zamanda ülke ekonomisine maddi getiri sağlayan bir unsur olduğu için kültürel varlıkların korunması ve gelecek nesillere aktarılması büyük önem taşımaktadır. Kültürel varlıkların korunması dört farklı gerekçeye dayanmaktadır (Tekeli, 2009'ten akt. Göğebakan, 2015, s. 51). 
1. Halka sağlıklı bir tarih bilinci aşılamak,

2. Halkta ulus olma bilinci oluşturmak,

3. Kültürel varlıkların taşımış olduğu tarihi mimari ve estetik değerleri korumak ve

4. Kültürün turizme olan ekonomik katkılarını korumak ve sürdürülebilir kılmak.

Kültür turizmi geleneksel turizmin bir yan ürünü olarak turistlerin ilgisini çektiği gibi doğrudan kültür turizmi olarak ta ilgi çekmektedir. Geleneksel turizmi tercih eden turistler dinlenme amaçlı tatil yaparken boş zamanlarını öğrenme, farklı kültürleri tanıma ve geçmişin izlerini takip etme gibi amaçlarla alternatif turizm kaynaklarından da yararlanmaktadırlar (Ablak vd., 2014). Yöresel festivaller, folklor, tiyatro, sergi vb. sanat etkinlikleri ile tarihi eserler, mimari eserler, inançlar, yaşam ve beslenme şekilleri, arkeolojik ve antropolojik kalıntılar vb. unsurlar turistler tarafindan ilgi çeken kültürel kaynaklardandır (Kozak, Kozak ve Kozak, 2011; Çetin, 2010).

Kültür turizminin son yıllarda turistler tarafından artan oranda tercih edilmesi, kültürel eserlerin gelecek nesillere aktarılmasının ve yaşatılmasının önemini daha da arttırmıştır. Kültür turizmi, bir ülkenin otantikliğini ve ayırt ediciliğini en iyi şekilde anlatan bir kavramdır (Usta, 2012). Ülkenin otantikliğini ve ayırt ediciliğini ayırt eden kültürün gelecek nesillere aktarılması ve devamlılığının sağlanabilmesi için gerekli olan bireylere tarihi ve kültürel değerlerin eğitim yoluyla aktarılmasıdır.

\section{Kültürel Miras ve Turizm}

Kültür, her ülke için gelecek nesillere aktarılması ve korunması gereken maddi ve manevi değerlerdir. Bu nedenle kültür, cetlerin nesillere bıraktığı kültürel bir milli mirastır. Kültürel miras "atalardan emanet alınan ve gelecek nesillere birakllmast gereken somut ve soyut niteliklere sahip insana ait olan her türlü fiziksel eserler ile bir topluma ait soyut değerler bütünü” dür (Can, 2009). UNESCO (2005) ise kültürel mirası önceki kuşaklar tarafından oluşturulmuş ve evrensel değerlere sahip olduğuna inanılan mimari eserler, yazıtlar, mağara konutları, tarih, sanat, doğa ve insanın birleşik eserleri, otantik yaşam, folklor, dil vb. yaşanmışlıklardan bugüne kalanlara verilen genel bir isim olarak tanımlamaktadır. Kültürel miras, geçmişten miras alınan, toplumsal yaşamda kabul edilen, yaşanan ve gelecek nesillere aktarılması gereken somut ve soyut kavramlar taşıyan ve insanlar, insan-doğa işbirliği sonucu meydana getirilen her türlü eserler ile toplumsal değerler olarak kabul edilmektedir (Akpirinç ve Manc1, 2019).

Kültürel miras, toplumların geçmişlerini bugüne ve geleceğe taşıyan ve toplumun fiziksel ve sosyal yaşamlarını gelecek nesillere aktaran somut ve soyut değerlerdir. Bu nedenle toplumların kültürel mirasını koruması ve gelecek nesillere aktarması kendi tarihini ve varlığını geleceğe aktarması demektir (Akay, 2006). Bu nedenle, kültürel varlıkların sürdürülebilirliğinin sağlanması ve korunması için toplum tarafindan fark edilmesi gerekmektedir (Tören, Kozak ve Demiral, 2012). Bu fark edilmeye katkı sağlayacak unsurlardan birisi de turizmdir.

Son yıllarda kültürel miras ve turizm ilişkisi üzerine akademisyenler tarafindan çalışmalar yapılmaktadır. Bu çalışmalarda bilim insanları miras turizminin, miras/kültürel cazibe merkezlerini ziyaret eden turistlerin ziyaret ettikleri miras türlerini tanımlamak için bir firsat sunduğunu belirtmektedirler (Nguyen ve Cheung, 2014). Su ve Wall (2011), Kültürel miras ve turizm ilişkisi üzerine yapılan çalışmaların iki araştırma çizgisini takip ettiğini belirtmektedir. Birincisi; miras, kültürel miras ve turizm ilişkisinin tanımlanması, ikincisi ise, kültürel mirasın korunması ile turizmin gelişimi arasındaki ilişkinin araştırılmasıdır. 


\section{Kültürel Miras Farkındalığı}

Mirasın korunması (Carbone, Oosterbeek ve Costa, 2012) ve yönetilmesinin önemli bileşenlerinden birisi miras farkındalığıdır. Zamanla gelişen kültürel farkındalık aynı zamanda yerel toplumun sadakati ve verdiği destek ile ilgilidir (Srivastava, 2015). Geçmişten günümüze kültürel mirasların zarar görmesinin en önemli nedenleri arasında toplumda farkındalık eksikliği olması ve koruma sürecinde aktif rol almamalarıdır. Kültürel mirasın korunmasında yerel toplumun desteğine ihtiyaç vardır. $\mathrm{Bu}$ destek, yerel toplumun değerlerinin farkında olması, onunla gurur duyması ve aidiyet duygusuna sahip olması ile sağlanabilir (Shankar ve Swamy, 2013). Kültür mirasını korumak ve gelecek nesillere aktarmak tamamen toplumun bir sorumluluğu olup bu sorumluluk duygusunun oluşmasında ise eğitim politikaları, eğitim kurumları ve öğretmenlerin rolleri yadsınamayacak boyuttadır (Srivastava, 2015).

Kültürel mirasın ticari olarak anlam ifade edebilmesi için korunması ve gelecek nesillere aktarılması büyük önem taşıması gerekmektedir. Ülkeler bu amaçla tarihi ve kültürel mirası korumak için yasal düzenlemeler yapmaktadırlar. Yasal düzenlemeler, kültürel mirasın korunmasında oldukça önemlidir. Ancak bu düzenlemelerin anlam ifade edebilmesi için bireylerin ve bütün olarak toplumda da farkındalık oluşturulması gerekmektedir (Sürücü ve Başar, 2016).

Kültürel miras farkındalığı üzerine yerli ve yabancı literatürde sınırlı çalışmalara rastlamak mümkündür. Kültürel miras farkındalığını belirlemek amacıyla yapılan çalışmaların üniversite öğrencileri, yerel halk, öğretmenler ve ilk-ortaöğretim öğrencileri üzerine yoğunlaştığ görülmektedir. Literatürde kültürel miras farkındalığı üzerine yapılan çalışmalardan bazılarına aşağıda yer verilmektedir.

Uslu ve Kiper (2006) tarafından yapılan araştırmada, Beypazarı halkının kültürel miras farkındalığı belirlenmeye çalışılmıştır. Bu çalışmada, yerel halkın yöreye özgü mimari dokular ve el sanatları kültürünün farkında olduğu belirlenmiştir. Ayrıca yöresel yemeklerin talep görmesi ve korunmasına yönelik farkındalık ortaya konmuştur.

Akkuş, Karaca ve Polat'ın (2015), öğrencilerin kültürel miras farkındalığına yönelik Sivas ilinde yaptıkları çalışmada, Sivaslı olan, üst sınıflarda okuyan ve turizm eğitimi alan öğrenciler ile diğer öğrenciler arasında Sivas'ın kültürel miraslarına ilişkin farkındalık ve deneyimleme algılarının anlamlı bir şekilde farklılaştığı görülmektedir. Fakat bu farkındalık orta ve düşük düzeydedir.

Güneş ve Alagöz (2018) kültürel miraslara ilişkin tutumlarını belirlemek amacıyla turizm alanında öğrenim gören üniversite öğrencilerine yönelik bir araştırma yapmıştır. Kültürel miras unsurlarına yönelik öğrencilerin tutumlarının genel olarak olumlu olduğuna dair bulgulara ulaşılmıştır.

Keçe (2015) tarafından öğretmen adaylarının Ankara ilinin tarihi ve kültürel turizm değerlerine ilişkin yapılan farkındalık araştırmasında, kültür turizmine ilgili duyan öğretmenlerin diğer turizm türlerine ilgi duyanlara göre farkındalık sahibi oldukları tespit edilmiş olup yeterli düzeyde bilgiye sahip olmadıkları anlaşılmaktadır.

Ablak vd.'nin (2014) Kırşehir ilinde yaptıkları farkındalık çalışmasında ise, sosyal bilimler öğretmenliği eğitimi alan öğrencilerin Kırșehir ilinin tarihi ve kültürel değerlerine yönelik tutumlarının sınıf öğretmenliği eğitimi alan öğrencilere göre daha yüksek olduğu belirlenmiştir. Ayrıca üst sınıfta okuyan öğrencilerin alt sınıftakilere göre kültürel değerlere ilişkin tutumlarının yüksek olduğu tespit edilmiştir.

Mancı (2019) Şanlıurfa'nın tarihi ve kültürel eserlerine yönelik öğrencilerin kültürel miras farkındalığı ve deneyimlerine sahip olup olmadıklarını araştırmıştır. Çalışmanın bulgularına göre, 
Şanlıurfa'nın kültürel değerlerine ilişkin öğrenciler yüksek düzeyde farkındalık ve deneyim düzeyine sahiptirler.

Srivastava (2015) tarafından yapılan çalışmanın bulguları, erkek ve kadın öğretmenlerin kültürel miras konusunda farkındalığa sahip olduğunu ortaya koymaktadır. Detaylı incelendiğinde, kadın öğretmenlerin erkeklere oranla daha fazla farkındalığa sahip olduğu anlaşılmaktadır.

Karadeniz (2020) ise Türkiye'nin kültürel mirasları ve varlıkları hakkında, coğrafya bölümünde öğrenim gören öğrencilerin algı ve farkındalıklarını belirlemek amacıyla bir çalışma yapmıştır. Araştırmanın sonucunda, öğrencilerin farkındalıklarının orta düzeyde olduğuna dair bulgular edinmiştir.

Halaç, Mokrane ve Turan (2019) Eskişehir Anadolu Üniversitesi'nde, TÖMER'den eğitim alan öğrencilerin kültürel miraslara olan ilgisini araştırmışlardır. Araştırma bulgularına göre, öğrencilerin kültürel miraslara ilişkin farkındalığı ve bilgileri olduğu ve bir kısmının bu yerleri ziyaret ettikleri tespit edilmiştir.

Kırgızistan'a dair İnce ve Samatova (2018) Kırgız mutfağına ilişkin öğrencilerin farkındalık düzeylerini belirlemek amacıyla bir çalışma yapmışlardır. Bulgulara göre, öğrencilerin Kırgız mutfağına ilişkin farkındalıklarının ve deneyimleme düzeylerinin yüksek olduğu belirtilmektedir.

\section{Kırgızistan'ın Kültürel Miras Kaynakları}

Kırgızistan, ipek yolu, binlerce metreyi bulan zirvelerle donatılmış dağları, flora ve faunası, ırmaklar ve gölleriyle birlikte pek çok turizm kaynaklarına sahiptir. Kırgızistan'ın atları "Kırgızistan rüzgarı olarak" atasözlerinde yer bulmuştur. Kırgız atları, "at-çabuş (At-Chabysh), "Kök-Börü" (Ulak-tartysh) ve "Kyz- kuumai" gibi birçok geleneksel yarışın ana figürü olarak kullanılmaktadır. Kırgızistan, turistler için kültürel farkındalık oluşturabilecek birçok somut ve soyut kültürel mirasa sahiptir. Bu kültürel eserlerin bazıları UNESCO tarafından kültürel miras listesine alındığı bilinmektedir.

Kırgızistan imajını yansıtan önemli pek çok değerlerin olduğu bilinmekle birlikte bunlar somut ve somut olmayan kültürel miras olarak UNESCO tarafindan tanımlanmıştır. Kırgızistan'ın UNESCO tarafindan belirlenen dünya miras listesindeki varlıkları ve kabul edilme tarihleri aşağıda ifade edilmiştir. Bunlar (UNESCO, 2020):

1. Kutsal Süleyman Dağı (2009)

2. İpek Yolu: Çang'an-Tiyanşan Koridoru Ulaşım Ağı (2014) (Çin ve Kazakistan ile paylaşılmaktadır.)

3. Batı Tanrı Dağları (2016) (Kazakistan ile paylaşılmaktadır.)

UNESCO tarafından ilan edilen Kırgızistan'ın Somut Olmayan Kültürel Mirası listesindeki değerler ve kabul edilme tarihleri ise aşağıda yer almaktadır. Bunlar:

1. Kökbörü / Geleneksel At Oyunu, (2017)

2. Nevruz, (2009-2016)

3. İnce Ekmek Yapma ve Paylaşma Kültürü: Lavaş, Katırma, Jupka, Yufka, (2016)

4. Atiesh / Aitys, Doğaçlama Sanatı, (2015)

5. Kazak ve Kırgız Yurtlarının (Türk Göçebe Konutları) Yapımındaki Geleneksel Bilgi ve Beceriler, (2014)

December-2020 Vol:5 No:2 International Journal of Turkic World Tourism Studies 
6. Kırgız Destan Üçlemesi: Manas, Semetey, Seytek, (2013)

7. Kırgız Destan Anlatıcısı, Ozanların Sanatı, (2008)

8. Ak-kalpak işçiliği, Kırgız erkek şapkaları yapma ve takma konusundaki geleneksel bilgi ve beceriler (2019) (Araştırma verilerinin toplandığ 1 tarihte henüz kabul edilmedi)

UNESCO tarafından ilan edilen Kırgızistan'ın Acil Koruma Gerektiren Somut Olmayan Kültürel Miras Listesi'ndeki değerler ve kabul edilme tarihleri ise aşağıda ifade edilmektedir. Bunlar:

1. Ala Kiyiz ve Shyrdak, Geleneksel Kırgız Keçe Halı Sanatı, (2012)

\section{YÖNTEM}

\section{Araştırmanın Amacı ve Önemi}

$\mathrm{Bu}$ çalışmanın temel amacı, Kırgızistan'ın kültürel miras unsurlarına ilişkin üniversite öğrencilerinin farkındalıklarının belirlenmesidir. $\mathrm{Bu}$ amaçla Önem-Performans Analizinden (Importance-Performance Analysis-IPA) yararlanarak Bilinirlik-Deneyimleme Analizi-BDA (Familiarity-Experience Analysis-FEA) geliştirilmiştir. Bilinirlik ve deneyimleme düzeylerinin karşılaştırılması sonucunda UNESCO tarafindan onaylanan Kırgızistan'a ait kültürel miras unsurlarının farkındalık durumu ortaya konulmaya çalışılmıştır. Literatürde kültürel miras farkındalığ ilişkin farkındalık çalışmalarına rastlanmamıştır. Ayrıca literatür incelendiğinde, kültürel miras farkındalığını değerlendirme amaçlı Önem-Performans Analizinin kullanıldığı çalışmalara da rastlanmamıştır. Bu yönüyle çalışmanın literatüre önemli katkılar sağlayacağı tahmin edilmektedir. $\mathrm{Bu}$ gerekçelerle, Kırgızistan'ın kültürel miras unsurlarına yönelik bilinirlik ve deneyimleme anlamında üniversite öğrencilerinin kültürel miras farkındalığının ortaya konulmasının önemli olduğu düşünülmekte ve aşağıdaki sorulara cevaplar aranmaktadır.

- Kırgızistan'ın kültürel miras unsurlarının üniversite öğrencileri tarafından bilinirlik düzeyi nedir?

- Kırgızistan'ın kültürel miras unsurlarının üniversite öğrencileri tarafindan deneyimleme düzeyi nedir?

- Kırgızistan'ın kültürel miras unsurlarının üniversite öğrencileri açısından farkındalık düzeyi nedir?

\section{Veri Toplama Aracının Geliştirilmesi}

Literatüre ilişkin yapılan inceleme sonucunda veri toplama aracı olarak anket geliştirilmiştir. Anket üç bölümden oluşmaktadır. Anketin birinci bölümünde, demografik sorulara (cinsiyet, yaş, aylık aile gelir düzeyi, milliyet, ailenin yaşadığı yer, öğrenim görülen birim, sınıf) yer verilmiştir. İkinci bölümde, kültürel miras unsurlarının bilinirlik düzeylerini belirlemek amacıyla UNESCO tarafindan onaylanan Kırgızistan'a ait 11 somut ve somut olmayan kültürel miras unsurunu kapsayan "Kültürel Miras Bilinirlik Ölçeği”ne (1: Hiç Bilmiyorum- 5: Çok İyi Biliyorum) yer verilmiştir. Üçüncü bölümde ise, kültürel miras deneyimleme düzeylerinin belirlenmesi amaciyla UNESCO tarafindan belirlenen Kırgızistan'a ait 11 somut ve somut olmayan kültürel miras unsurunu kapsayan "Kültürel Miras Deneyimleme Ölçeği”ne yer verilmiştir. Deneyimleme ölçeğinde, katılımcıların tarihi yapıları ne sıklıkta ziyaret ettikleri (1: Hiç gitmedim - 5:Her zaman giderim), el sanatlarını ne sıklıkta satın aldıkları (1:Hiç satın almadım - 5:Her zaman alırım), bazı miras unsurlarını ne düzeyde deneyimledikleri (1:Hiç - 5:Her zaman), etkinliklere ne sıklıkta katıldıkları (1: Hiç izlemedim - 5: Her zaman izlerim), doğal varlıkları ne sıklıkta ziyaret ettikleri (1: Hiç gitmedim - 5: 
Her zaman giderim) Likert tipi 5'li aralıklı ölçek ile sorgulanmıştır. Kültürel Miras Bilinirlik ve Deneyimleme Ölçekleri, Akkuş vd. (2015) tarafindan geliştirilen ölçeklerden yararlanarak Kırgızistan'a uyarlanarak KTMÜ öğrencilerine uygulanmıştır.

\section{Evren ve Örneklem}

Araştırmanın evrenini KTMÜ'de öğrenim gören öğrenciler oluşturmaktadır. Araştırmanın yapıldığ 1 15 Nisan-10 Mayıs 2019 tarihleri arasında KTMǗde 5921 lisans ve önlisans öğrencisi öğrenim görmektedir. Evrenin boyutuna göre \%5 hata payıyla 361 kişiye ulaşılmas1 gerekmektedir. Araştırmada kullanılan anket, tesadüfi olmayan örnekleme yöntemlerinden kolayda örnekleme yöntemi ile yüz yüze ve elektronik olarak uygulanmış ve 408 anket geri dönmüştür.

\section{Verilerin Analizi}

Verilerin analizinde betimsel istatistiklerden frekans, yüzde, aritmetik ortalama ve standart sapma değerleri kullanılmıştır. Üniversite öğrencilerinin Kırgızistan'ın kültürel miras unsurlarına ilişkin farkındalık durumunu belirlemek için Martilla ve James (1977) tarafından geliştirilen ÖnemPerformans Analizi-ÖPA (Importance-Performance Analysis-IPA) ve Yang (2003) tarafindan geliştirilen Önem-Memnuniyet Analizi-ÖMA (Importance-Satisfaction Analysis-ISA) modellerinden yararlanarak "Bilinirlik-Deneyimleme Analizi-BDA" (Familiarity-Experience Analysis-FEA) geliştirilmiştir. Bilinirlik-Deneyimleme Analizi ile Kırgızistan'ın kültürel miraslarına ilişkin üniversite öğrencilerinin algıları belirtilen ölçekler yardımıyla analiz edilmiş ve yorumlanmıştır.

\section{Güvenirlik ve Geçerlik}

Ölçeklerin güvenirliğinin belirlenmesi amacıyla yapılan analiz sonucunda Cronbach alfa katsayıları "Kültürel Miras Bilinirlik Ölçeği” için 0,909 ve "Kültürel Miras Deneyimleme Ölçeği” için 0,763 olarak tespit edilmiştir. Literatüre göre Cronbach alfa katsayılarının 0.70 'den büyük olması ölçeklerin güvenilir olduğunu göstermektedir (Coşkun, Altunışık, Bayraktaroğlu ve Yıldırım, 2015, s. 126; Saruhan ve Özdemirci, 2013, s. 211). Ölçeklerin içerik geçerliliği açısından amaca uygun olup olmadığı uzman görüşleri çerçevesinde doğrulanmıştır. Ayrıca 15 öğrenci üzerinde pilot çalışma yapılarak elde edilen geribildirimler doğrultusunda ölçekler üzerindeki eksiklikler giderilmiştir. Ölçeklere ilişkin ortalamaların çarpıklık ve basıklık düzeyleri \pm 1.5 arasında değişmektedir. Bu sonuç verilerin normal dağılıma uygun olduğunu göstermektedir (Tabachnick ve Fidell, 2013).

\section{BULGULAR}

\section{Demografik Bulgular}

Katılımcıların demografik özelliklerinin dağılımı Tablo 1'de yer almaktadır. Tablo 1 incelendiğinde, katılımcıların, \%72.1'inin kadın; \%47.8'nin 20-21 yaş arasında; \%84.8'inin Kırgızistan ve \% 15.2'sinin diğer ülke vatandaşı; \%42.1'inin 10.000 ve 20.000 KGS arasında gelire sahip; \%49'unun Turizm ve Otelcilik Yüksekokulunda öğrenim gördüğü; \%29.9'unun I. Sınıf ve \%29.9'unun II. Sinıf olduğu tespit edilmiştir. 
Tablo 1. Demografik Bulgular

\begin{tabular}{|c|c|c|c|}
\hline \multicolumn{2}{|l|}{ Demografik Özellikler } & $\mathbf{f}$ & $\%$ \\
\hline \multirow{2}{*}{ Cinsiyet } & Kadın & 294 & 72.1 \\
\hline & Erkek & 114 & 27.9 \\
\hline \multirow{3}{*}{ Yaş } & 20 yaș altı & 110 & 27.1 \\
\hline & 20-21 yaş arası & 194 & 47.8 \\
\hline & 22 yaş ve üzeri & 102 & 25.1 \\
\hline \multirow{2}{*}{ Milliyet } & Kirgizistan & 346 & 84.8 \\
\hline & Diğer Ülkeler & 62 & 15.2 \\
\hline \multirow{6}{*}{ Gelir } & 5.000 Som ve altında & 32 & 7.8 \\
\hline & $5.001-10.000$ aras1 & 70 & 17.2 \\
\hline & $10.001-15.000$ aras1 & 78 & 19.1 \\
\hline & $15.001-20.000$ aras1 & 94 & 23.0 \\
\hline & $20.001-25.000$ aras1 & 66 & 16.2 \\
\hline & 25.001 Som ve üzeri & 68 & 16.7 \\
\hline \multirow{3}{*}{ Ailenin yaşadığı yer } & İl & 82 & 20.1 \\
\hline & İlçe & 96 & 23.5 \\
\hline & Köy & 230 & 56.4 \\
\hline \multirow{3}{*}{ Akademik birim } & Lisans (Turizm ve Otelcilik YO) & 200 & 49.0 \\
\hline & Önlisans (MYO) & 122 & 29.9 \\
\hline & Lisans (Diğer) & 86 & 21.1 \\
\hline \multirow{5}{*}{ Sinıf } & Hazırlık & 46 & 11.3 \\
\hline & I. Sinif & 122 & 29.9 \\
\hline & II. Sinif & 122 & 29.9 \\
\hline & III. Sinıf & 62 & 15.2 \\
\hline & IV. Sinıf & 56 & 13.7 \\
\hline
\end{tabular}

\section{Kültürel Miras Farkındalığına İliş kin Bulgular}

Üniversite öğrencilerinin Kırgızistan'ın kültürel miras unsurlarına ilişkin farkındalık durumunu belirlemek amacıyla iki analiz gerçekleştirilmiştir. Birincisi Martilla ve James (1977) tarafindan geliştirilen Önem-Performans Analizi-ÖPA (Importance-Performance Analysis-IPA) ve Yang (2003) tarafından geliştirilen Önem-Memnuniyet Analizi-ÖMA (Importance-Satisfaction AnalysisISA) modellerinden yararlanarak uyarlanan "Bilinirlik-Deneyimleme Analizi-BDA" (FamiliarityExperience Analysis-FEA). İkincisi ise bilinirlik ve deneyimleme ölçeklerinde yer alan kültürel miras unsurlarının aritmetik ortalamalarına göre aralarında istatistiki olarak anlamlı bir fark olup olmadığını belirlemeye yönelik Eşleştirilmiş örneklem t-testidir (Paired-sample t.test). Kültürel Miras Bilinirlik ve Deneyimleme Ölçeklerine ilişkin betimsel istatistiki bilgiler ve BDA sonucu her bir kültürel miras unsurunun yer alacağı alanlar Tablo 2'de görülmektedir.

Tablo 2. Kültürel Miras Unsurlarına İlişkin Betimsel İstatistiki Bulgular ve Alan Bilgisi

\begin{tabular}{|l|c|c|c|c|c|c|c|}
\hline \multirow{2}{*}{ Kültürel Miras Unsurları } & \multirow{2}{*}{$\mathbf{N}$} & \multicolumn{2}{c|}{ Bilinirlik } & \multicolumn{2}{c|}{ Deneyimleme } & \multirow{2}{*}{ Fark } & \multirow{2}{*}{ Alan } \\
\cline { 5 - 8 } & & $\overline{\mathbf{x}}$ & $\mathbf{S s}$ & $\overline{\mathbf{x}}$ & $\mathbf{s s}$ & & \\
\hline 1. Kutsal Süleyman Dağı & 408 & 3.85 & 1.048 & 1.87 & 1.039 & 1.98 & II \\
\hline $\begin{array}{l}\text { 2. İpek Yolu: Çang'an-Tiyanşan Koridoru } \\
\text { Ulaşım Ağ1 }\end{array}$ & 408 & 3.18 & 1.135 & 2.78 & 0.854 & 0.40 & IV \\
\hline 3. Batı Tanrı Dağları (Tien-Shan) & 408 & 3.36 & 1.102 & 1.57 & 0.830 & 1.79 & III \\
\hline 4. Kökbörü / Geleneksel At Oyunu & 408 & 4.09 & 1.026 & 2.00 & 1.132 & 2.08 & II \\
\hline 5. Nevruz & 408 & 4.43 & 0.941 & 3.68 & 1.091 & 0.75 & I \\
\hline
\end{tabular}




\begin{tabular}{|c|c|c|c|c|c|c|c|}
\hline $\begin{array}{l}\text { 6. İnce Ekmek Yapma ve Paylaşma } \\
\text { Kültürü: Lavaş, Katırma, Jupka, Yufka }\end{array}$ & 408 & 3.61 & 1.157 & 3.04 & 1.036 & 0.56 & IV \\
\hline 7. Atışma / Aitys Doğaçlama Sanatı & 408 & 3.57 & 1.169 & 2.55 & 1.022 & 1.02 & IV \\
\hline 8. Boz Üy Yapımı & 408 & 3.72 & 1.146 & 2.41 & 1.221 & 1.31 & III \\
\hline $\begin{array}{l}\text { 9. Kırgız Destan Üçlemesi: Manas, } \\
\text { Semetey, Seytek }\end{array}$ & 408 & 4.09 & 0 & 3.50 & 1.065 & 0.58 & I \\
\hline 10. Manasçılar: Ozanların Sanatı & 408 & 3.85 & 1.064 & 2.11 & 1.025 & 1.74 & II \\
\hline $\begin{array}{l}\text { 11. Ala Kıyız ve Shyrdak, Geleneksel } \\
\text { Kırgız Keçe Halı Sanatı }\end{array}$ & 408 & 3.66 & 1.189 & 2.07 & 1.097 & 1.59 & III \\
\hline
\end{tabular}

\section{Bilinirlik-Deneyimleme Analizi (BDA) Sonuçları}

Önem-Performans Analizi (Importance-Performance Analysis-IPA), pazarlama alanında hangi ürün/hizmetlere önem verildiği takdirde müşteri tatminin sağlanabileceği konusunda yol gösterici bir tekniktir. Önem-Performans Analizi'nde, öncelikli olarak ürün/hizmete ilişkin müşterilerin algıladığı önem düzeyi ve algıladıkları performans (memnuniyet) belirlenmektedir. Daha sonra ise önem ve performans skorları tespit edilmektedir. Elde edilen skorlar x ve y koordinat değerleri olup $\mathrm{x}$ ekseninde performansın (memnuniyet) $\mathrm{y}$ ekseninde ise önemin bulunduğ matriste gösterilmektedir (Albayrak ve Caber, 2011, s. 628).

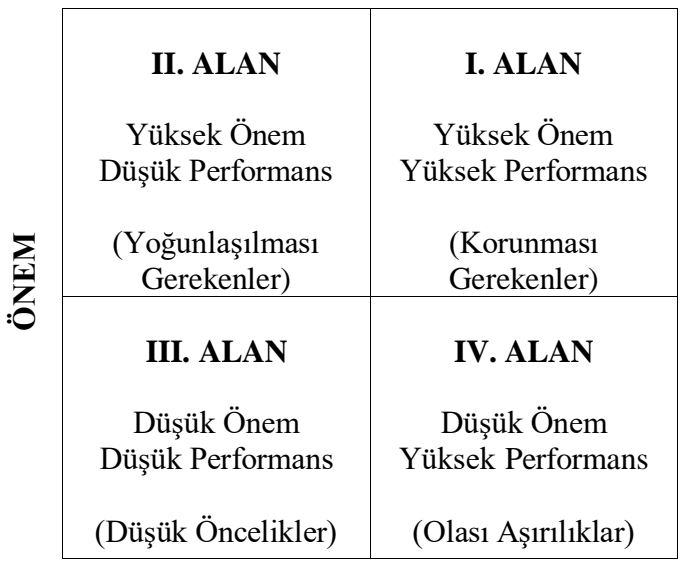

PERFORMANS

Şekil 1. Önem-Performans Matrisi

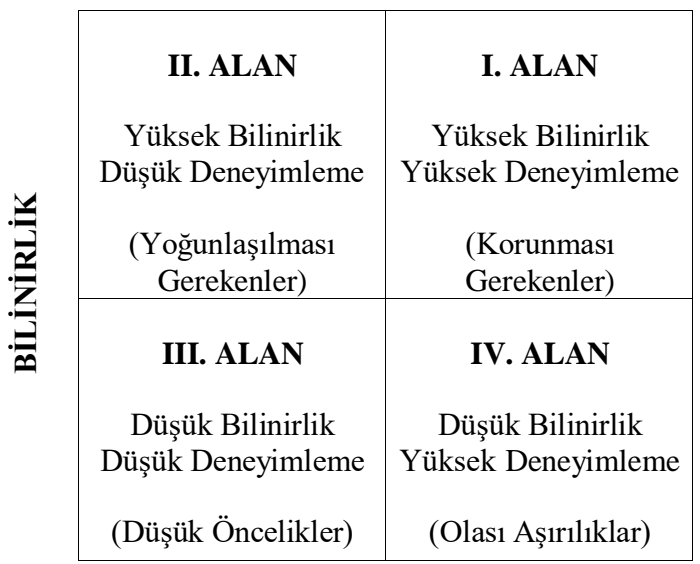

DENEYIMLEME

Şekil 2. Bilinirlik-Deneyimleme Matrisi

Önem-Performans Matrisi (Şekil 1), çalışma konusu olan kültürel miras unsurlarına ilişkin Bilinirlik-Deneyimleme Matrisi (Şekil 2) olarak uyarlanmıştır. Bu uyarlama sonucunda, Kırgızistan'ın kültürel miraslarına ilişkin üniversite öğrencileri tarafından bilinirlik ve deneyimleme algıları öncelikli olarak belirlenmiştir. Sonrasında her bir kültürel miras unsuru için bilinirlik ve deneyimleme skorları tespit edilmiştir. Elde edilen skorlar $\mathrm{x}$ ve $\mathrm{y}$ koordinat değerleri olup $\mathrm{x}$ ekseninde deneyimleme ve y ekseninde bilinirlik olarak matriste gösterilmiştir. Koordinat değerlerinin belirlenmesinde bilinirlik ve deneyimleme ortalamaları her bir kültürel miras unsuru için hesaplanmış ve eksenlerinin kesişme noktası belirlenmiştir.

Eksenlerin kesişme noktası hem bilinirlik düzeyinde hem de deneyimleme düzeyinde yer alan 11 kültürel mirasa ilişkin aritmetik ortalama değerlerinin ortalaması alınarak belirlenmiştir. Bilinirlik düzeyi için 11 unsurun aritmetik ortalama değerlerinin ortalaması 3.76 ve deneyimleme düzeyi için 
2.51 olarak tespit edilmiş ve her bir kültürel miras unsuru ortalama değerlere göre matriste konumlandırılmıştır (Tetik, 2012, s. 15). (Şekil 3)

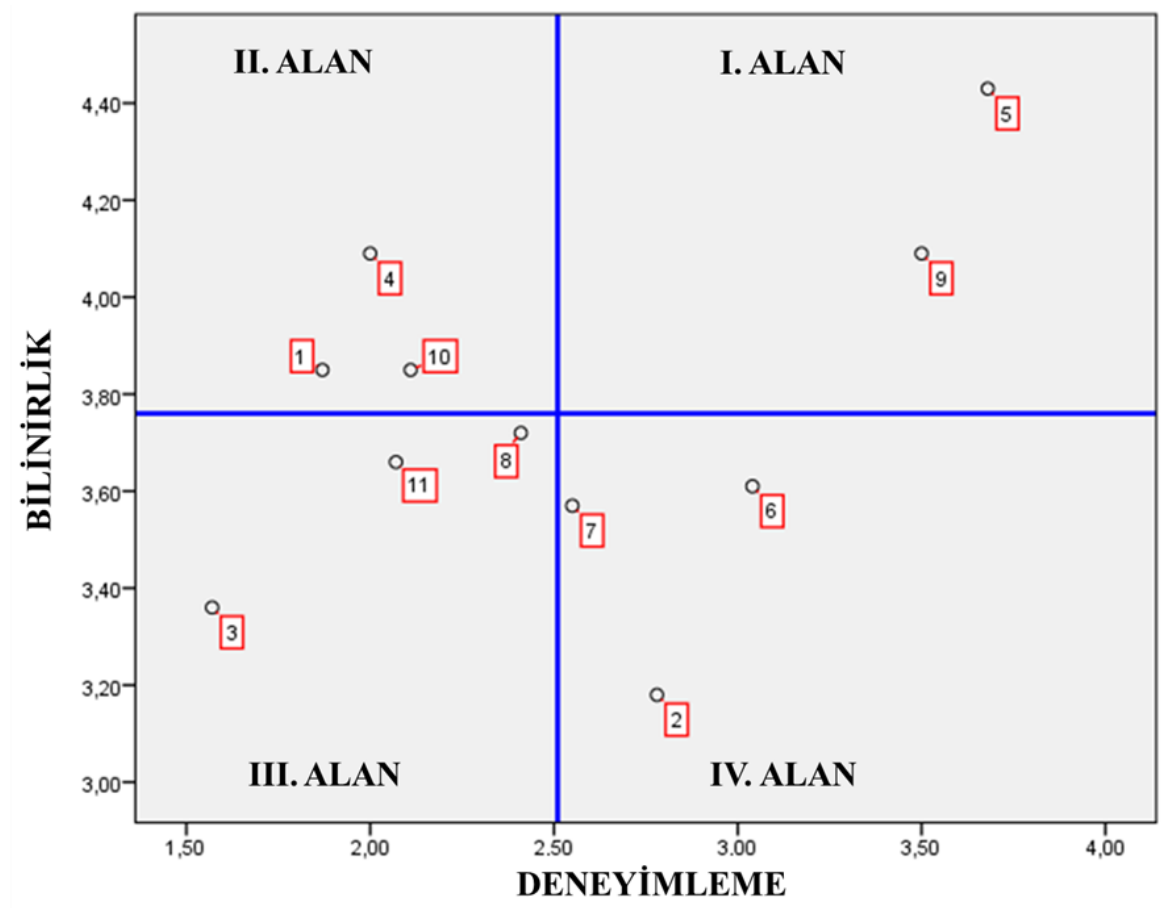

Şekil 3. Bilinirlik-Deneyimleme Analizi Sonuçları

BDA modeline ilişkin SPSS istatistik programı yardımıyla yapılan analiz sonucunda Kırgızistan'ın kültürel miraslarının bilinirlik-deneyimleme skorları matrise yerleştirilerek matriste konumlandığı alan (Şekil 3) ve bu alanların nitelikleri aşağıda belirtilmiştir.

I. Alan: Yüksek Bilinirlik-Yüksek Deneyimleme (Mükemmel Alan): Bu alanda 2 kültürel miras unsuru yer almıştır. Bunlar; "Nevruz" ve "Kırgız Destan Üçlemesi: Manas, Semetey, Seytek"dir. $\mathrm{Bu}$ alan, üniversite öğrencileri tarafindan bilinirlik ve deneyimleme düzeylerinin oldukça yüksek olduğu kültürel miras unsurlarının bulunduğu bölgedir. Başka bir ifadeyle, "Nevruz" ve "Kırgız Destan Üçlemesi: Manas, Semetey, Seytek" öğrenciler tarafından çok iyi bilinmekte ve aynı zamanda bu miras unsurlarına ilişkin katılımcıların çeşitli aktiviteleri sıklıkla deneyimledikleri söylenebilir. Bu alanda yer alan kültürel miras unsurlarının mevcut şekilde bilinirlik-deneyimleme düzeyleri korunmalıdır.

II. Alan: Yüksek Bilinirlik-Düşük Deneyimleme (Geliştirilmesi Gerekenler Alanı): Bu alanda 3 kültürel miras unsuru yer almaktadır. Bunlar; "Kutsal Süleyman Dağı”, "Kökbörü / Geleneksel At Oyunu" ve "Manasçılar: Ozanların Sanatı"dır. Bu alan üniversite öğrencileri tarafından bilinirlik düzeyleri yüksek olup deneyimleme düzeylerinin düşük olduğu bölgedir. Bu alandaki kültürel miras unsurları katılımcılar tarafından iyi bilinmesine rağmen bu kültürel miras unsurlarına yönelik aktiviteleri sıklıkla takip etmedikleri anlaşılmaktadır. Bu nedenle, bu alanda yer alan kültürel miras unsurlarına yönelik insanların ilgisini çekmek ve katılım oranlarını artırmak için çaba sarf edilmesi gerekmektedir. 
III. Alan: Düşük Bilinirlik-Düşük Deneyimleme (Eksiklikler Alanı): Bu alanda 3 kültürel miras unsuru yer almaktadır. Bunlar; "Batı Tanrı Dağları (Tien-Shan)", "Boz Üy Yapımı" ve "Ala Kıyız ve Shyrdak, Geleneksel Kırgız Keçe Halı Sanatı"dır. Bu alanda yer alan kültürel miras unsurları üniversite öğrencileri tarafindan düşük düzeyde bilinmekte olup aynı zamanda deneyimleme düzeyleri de düşüktür. Bu kültürel miras unsurlarının öncelikli olarak görülmediği ifade edilebilir.

IV. Alan: Düşük Bilinirlik-Yüksek Deneyimleme (Fazlalıklar Alanı): Bu alanda 3 kültürel miras unsuru yer almaktadır. Bunlar; "İpek Yolu: Çang'an-Tiyanşan Koridoru Ulaşım Ağı”, "İnce Ekmek Yapma ve Paylaşma Kültürü: Lavaş, Katırma, Jupka, Yufka" ve "Atışma / Aitys Doğaçlama Sanatı"dır. Bu alanda yer alan kültürel miras unsurlarının bilinirlik düzeylerinin düşük olmasına rağmen deneyimleme düzeylerinin yüksek olduğu anlaşılmaktadır. Katılımcıların bu alandaki kültürel miras unsurları hakkında yeterli bilgi sahibi olmadıkları halde çok fazla deneyimledikleri ifade edilebilir.

Tablo 3. Kültürel Miras Unsurlarının Bilinirlik ve Deneyimlenme Düzeylerine İlişkin Karşılaştırma

\begin{tabular}{|c|c|c|c|c|c|c|}
\hline Kültürel Miras Unsurları & $\begin{array}{c}\text { Bilinirlik / } \\
\text { Deneyimleme }\end{array}$ & $\overline{\mathbf{X}}$ & SS & $\overline{\mathbf{X}}_{\mathbf{B}}-\overline{\mathbf{X}}_{\mathbf{D}}$ & $\mathbf{t}$ & $\mathbf{p}$ \\
\hline \multirow{2}{*}{ 1. Kutsal Süleyman Dağı } & Bilinirlik & 3.85 & 1.048 & \multirow{2}{*}{1.98} & \multirow{2}{*}{33.348} & \multirow{2}{*}{$0.000 *$} \\
\hline & Deneyimleme & 1.87 & 1.039 & & & \\
\hline \multirow{2}{*}{$\begin{array}{l}\text { 2. İpek Yolu: Çang'an-Tiyanşan Koridoru Ulaşım } \\
\text { Ağ1 }\end{array}$} & Bilinirlik & 3.18 & 1.135 & \multirow{2}{*}{0.40} & \multirow{2}{*}{7.461} & \multirow{2}{*}{$0.000^{*}$} \\
\hline & Deneyimleme & 2.78 & 0.854 & & & \\
\hline \multirow{2}{*}{ 3. Batı Tanrı Dağları (Tien-Shan) } & Bilinirlik & 3.36 & 1.102 & \multirow{2}{*}{1.79} & \multirow{2}{*}{27.899} & \multirow{2}{*}{$0.000 *$} \\
\hline & Deneyimleme & 1.57 & 0.830 & & & \\
\hline \multirow{2}{*}{ 4. Kökbörü / Geleneksel At Oyunu } & Bilinirlik & 4.09 & 1.026 & \multirow{2}{*}{2.08} & \multirow{2}{*}{29.808} & \multirow{2}{*}{$0.000 *$} \\
\hline & Deneyimleme & 2.00 & 1.132 & & & \\
\hline \multirow{2}{*}{ 5. Nevruz } & Bilinirlik & 4.43 & 0.941 & \multirow{2}{*}{0.75} & \multirow{2}{*}{11.083} & \multirow{2}{*}{$0.000 *$} \\
\hline & Deneyimleme & 3.68 & 1.091 & & & \\
\hline \multirow{2}{*}{$\begin{array}{l}\text { 6. İnce Ekmek Yapma ve Paylaşma Kültürü: } \\
\text { Lavaş, Katırma, Jupka, Yufka }\end{array}$} & Bilinirlik & 3.61 & 1.157 & \multirow{2}{*}{0.56} & \multirow{2}{*}{8.309} & \multirow{2}{*}{$0.000 *$} \\
\hline & Deneyimleme & 3.04 & 1.036 & & & \\
\hline \multirow{2}{*}{ 7. Atışma / Aitys Doğaçlama Sanatı } & Bilinirlik & 3.57 & 1.169 & \multirow{2}{*}{1.02} & \multirow{2}{*}{16.965} & \multirow{2}{*}{$0.000^{*}$} \\
\hline & Deneyimleme & 2.55 & 1.022 & & & \\
\hline \multirow{2}{*}{ 8. Boz Üy Yapımı } & Bilinirlik & 3.72 & 1.146 & \multirow{2}{*}{1.31} & \multirow{2}{*}{18.882} & \multirow{2}{*}{$0.000 *$} \\
\hline & Deneyimleme & 2.41 & 1.221 & & & \\
\hline \multirow{2}{*}{$\begin{array}{l}\text { 9. Kırgız Destan Üçlemesi: Manas, Semetey, } \\
\text { Seytek }\end{array}$} & Bilinirlik & 4.09 & 0.947 & \multirow{2}{*}{0.58} & 10275 & $0000 *$ \\
\hline & Deneyimleme & 3.50 & 1.065 & & $10.2 / 5$ & $0.000^{*}$ \\
\hline & Bilinirlik & 3.85 & 1.064 & & & \\
\hline 10. Manasçılar: Uzanların Sanatı & Deneyimleme & 2.11 & 1.025 & 1.74 & 29.484 & $0.000^{*}$ \\
\hline 11. Ala Kıyız ve Shyrdak, Geleneksel Kırgız Keçe & Bilinirlik & 3.66 & 1.189 & & & \\
\hline Halı Sanatı & Deneyimleme & 2.07 & 1.097 & 1.59 & 21 & $0.000^{*}$ \\
\hline
\end{tabular}
$* \mathrm{p}<0,01$

\section{Eşleştirilmiş Örneklemler T-testi Sonuçları}

Kırgızistan'ın kültürel miras unsurlarına ilişkin bilinirlik ve deneyimleme düzeyleri arasında anlamlı bir farklılık olup olmadığını belirlemek için Eşleştirilmiş örneklem t-testi (Paired-sample ttest) yapılmıştır. Yapılan analiz sonucunda (Tablo 3), kültürel miras unsurlarının tamamının bilinirlik düzeyleri ile deneyimleme düzeyleri arasında anlamlı farklılık olduğu tespit edilmiştir. Tablo 3'te görüldüğü gibi kültürel miras unsurlarının bilinirlik düzeyi ortalamalarının deneyimleme düzeyi ortalamalarından yüksek olduğu anlaşılmaktadır. Kültürel miras unsurlarına ilişkin bilinirlik ve deneyimleme düzeyleri arasındaki aritmetik ortalama farkları incelendiğinde en yüksek fark oluşanlar, "Kökbörü / Geleneksel At Oyunu" (2.08), "Kutsal Süleyman Dağı" (1.98), "Batı Tanrı 
Dağları (Tien-Shan)" (1.79) ve "Manasçılar: Ozanların Sanatı" (1.74) olurken en düşük farka sahip olanların ise, "İpek Yolu: Çang'an-Tiyanşan Koridoru Ulaşım Ağı” (0.40), "İnce Ekmek Yapma ve Paylaşma Kültürü: Lavaş, Katırma, Jupka, Yufka" (0.56), "Kırgız Destan Üçlemesi: Manas, Semetey, Seytek" (0.58) ve "Nevruz" (0.75) olarak tespit edilmiştir.

\section{SONUÇ VE ÖNERILER}

$\mathrm{Bu}$ çalışmada, Önem-Performans Analizi (Importance-Performance Analysis-IPA) modelinden yararlanarak geliştirilen Bilinirlik-Deneyimleme Analizi-BDA (Familiarity-Experience AnalysisFEA) ile Kırgızistan'ın kültürel miraslarına ilişkin farkındalık düzeyi ortaya konulmaya çalışılmıştır. $\mathrm{Bu}$ amaç ile literatüre dayalı olarak geliştirilen Kültürel Miras Bilinirlik ve Deneyimleme ölçeklerini içeren bir anket Kırgızistan-Türkiye Manas Üniversitesi Lisans ve Önlisans programlarında öğrenim gören öğrencilere uygulanmıştır. Ayrıca çalışmada, Kültürel Miras Bilinirlik ve Deneyimleme Ölçeklerine ilişkin aritmetik ortalama değerleri kullanılarak eşleştirilmiş örneklem t-testi (Paired-sample t-test) yapılmıştır.

Bilinirlik-Deneyimleme Analizi (BDA) sonuçlarına göre Kırgızistan'ın kültürel miraslarından farkındalık düzeyi en yüksek olanların I. Alanda bulunanlar olduğu söylenebilir. I. Alanda bulunan kültürel miras unsurlarının hem bilinirlik hem de deneyimleme düzeyleri yüksektir. I. Alan içerisinde yer alan farkındalık düzeyi en yüksek olan kültürel miras unsurları arasında "Nevruz" $\left(\overline{\mathrm{X}}_{\mathrm{B}}=4.43, \overline{\mathrm{X}}_{\mathrm{D}}=3.68\right)$ ve "Kırgız Destan Üçlemesi: Manas, Semetey, Seytek" $\left(\overline{\mathrm{X}}_{\mathrm{B}}=4.09, \overline{\mathrm{X}}_{\mathrm{D}}=3.50\right)$ yer almaktadır. $\mathrm{Bu}$ alandaki kültürel miras unsurlarının farkındalığına ilişkin devamlılığın sağlanması ve korunması için çalışmalar yapılması önemlidir.

II. Alanda yer alan kültürel miras unsurlarının bilinirlik düzeyleri yüksek fakat deneyimleme düzeyleri düşüktür. Buna göre, II. Alanda yer alan unsurların kısmi farkındalık düzeyine sahip olduğu ifade edilebilir. II. Alandaki kısmi farkındalık düzeyine sahip kültürel miras unsurları arasında "Kökbörü / Geleneksel At Oyunu" $\left(\bar{X}_{B}=4.08, \bar{X}_{D}=2.00\right)$, "Kutsal Süleyman Dağg1" $\left(\bar{X}_{B}=3.85, \bar{X}_{D}=1.87\right)$ ve "Manasçılar: Ozanların Sanatı" $\left(\bar{X}_{B}=3.85, \bar{X}_{D}=2.11\right)$ bulunmaktadır. Bu alandaki kültürel miras unsurlarını katılımcılar bilmekte fakat deneyimleme anlamında yeteri kadar çaba göstermemektedirler. Bu alandaki kültürel miras unsurları üzerinde özellikle yoğunlaşılarak insanların deneyimleme anlamında Kökbörü organizasyonlarını izleme, Kutsal Süleyman Dağı'nı ziyaret etme ve Manasçıların yaptıkları programları izleme aktivitelerine daha fazla katılma firsatlarının sağlanması önemlidir.

III. Alanda yer alan kültürel miras unsurlarının hem bilinirlik hem de deneyimleme düzeylerinin düşük seviyede olduğu görülmüştür. Bu alanda yer alan unsurlara yönelik katılımcıların çok fazla merak ve ilgili duyduklarını söylemek mümkün değildir. Dolayısıyla bu alanda yer alan kültürel miras unsurlarının farkındalık düzeylerinin en düşük seviyede olduğu söylenebilir. Bu alanda yer alan kültürel miras unsurları arasında "Boz Üy Yapımı" $\left(\overline{\mathrm{X}}_{\mathrm{B}}=3.72, \overline{\mathrm{X}}_{\mathrm{D}}=2.41\right)$, "Ala Kıyız ve Shyrdak, Geleneksel Kırgız Keçe Halı Sanatı" $\left(\bar{X}_{B}=3.66, \bar{X}_{D}=2.07\right)$ ve "Batı Tanrı Dağları (TienShan)" $\left(\bar{X}_{B}=3.36, \bar{X}_{D}=1.57\right)$ yer almaktadır. Her ne kadar bu alanda kültürel miras farkındalığı oldukça düşük olsa da toplumun bilinçlendirilmesine yönelik çalışmalara yoğunlaşılması önem arz etmektedir. Ayrıca bu değerlerin kaybolmadan gelecek kuşaklara aktarılmasına destek olacak çalışmaların toplumun her kesiminin sorumluluğu olduğu kamuoyuna anlatılmalıdır.

Son olarak IV. Alanda yer alan kültürel miras unsurlarının bilinirlik düzeylerinin düşük deneyimleme düzeylerinin ise yüksek olduğu tespit edilmiştir. Bu sonuca göre, katılımcıların bu unsurları çok iyi bilmedikleri halde deneyimlediklerini göstermektedir. Bu alanda yer alan kültürel miras unsurları arasında "İnce Ekmek Yapma ve Paylaşma Kültürü: Lavaş, Katırma, Jupka, Yufka" 
$\left(\overline{\mathrm{X}}_{\mathrm{B}}=3.61, \overline{\mathrm{X}}_{\mathrm{D}}=3.04\right)$, “Atışma / Aitys Doğaçlama Sanatı" $\left(\overline{\mathrm{X}}_{\mathrm{B}}=3.57, \overline{\mathrm{X}}_{\mathrm{D}}=2.55\right)$ ve "İpek Yolu: Çang'an-Tiyanşan Koridoru Ulaşım A $\breve{g} 1$ ” $\left(\overline{\mathrm{X}}_{B}=3.18, \overline{\mathrm{X}}_{D}=2.78\right)$ yer almaktadır. IV. Alanda yer kültürel miras unsurlarının bilinirlik düzeyleri düşük olsa da deneyimleme düzeylerinin yüksekliği dikkate alındığında kısmi farkındalığa sahip olduğu söylenebilir. Bu alandaki kültürel miras unsurlarına ilişkin insanların bilgi düzeylerini artıracak çalışmalara önem vermek gerekirken deneyimleme düzeylerinin korunması da önemsenmelidir.

Kültürel miras unsurlarının bilinirlik ve deneyimleme düzeylerini belirlemeye yönelik testler ve aralarında anlamlı bir farklılık olup olmadığına dair yapılan eşleştirilmiş örneklemler t-testi sonuçlarına göre, Kırgızistan'ın tüm kültürel miras unsurlarının bilinirlik düzeylerinin deneyimleme düzeylerinden daha yüksek aritmetik ortalamalara sahip olduğu ve t-testi sonucuna göre aralarında anlamlı bir farklılık olduğu görülmüştür. Kültürel miras unsurlarının farkındalıklarına yönelik bilinirlik ve deneyimleme düzeyleri arasındaki fark ne kadar düşük olursa farkındalık düzeyinin o kadar yüksek olduğu, fark ne kadar yüksek olursa o kadar farkındalık düzeyinin düşük olacağını yapılan iki analiz göstermiştir. Bu bulgular, kültürel miras farkındalıklarına ilişkin yapılan araştırmalar ile ilgili olarak benzerlikler göstermektedir. Karaca, Akkuş, Şahbudak ve Işgın (2016) ve Akpirinç ve Mancı (2019) tarafından yapılan araştırmalarda benzer şekilde kültürel miras unsurlarının bilinirlik düzeylerinin deneyimleme düzeylerine göre yüksek olduğu ortaya çıkmıştır. Ayrıca kültürel miras unsurlarının genel farkındalığını belirlemeye yönelik yapılan çeşitli araştırmaların sonuçları (Karaca vd., 2016; Buluk, 2017) bu çalışmanın bulguları ile örtüşmekte olup kültürel miras unsurlarına ilişkin farkındalık düzeyleri orta ve düşük düzeyde olduğu tespit edilmiştir.

Önem-Performans Analizi (Importance-Performance Analysis-IPA) yoğun olarak işletme alanında ve nadiren de olsa eğitim bilimleri alanında çeşitli araştırmalarda kullanıldığı literatür üzerine yapılan incelemeler sonucunda tespit edilmiştir. Fakat Önem-Performans Analizinin, kültürel miras farkındalığı araştırmalarında bugüne kadar kullanıldığına yerli ve yabancı literatürde rastlanmamıștır. Bu kapsamda kültürel miras farkındalığı konusunda aynı analiz yöntemi ile yapılmış çalışmalara rastlanmasa da farklı yöntemler ile yapılan analizler mevcuttur. ÖnemPerformans Analizi'nin uyarlanarak kültürel miras farkındalığını tespit etmek amacıyla BilinirlikDeneyimleme Analizi (BDA) şeklinde uygulanan bu çalışma literatürde ilk olma özelliği taşımaktadır. $\mathrm{Bu}$ yönüyle özgün olan bu çalışmanın literatüre de önemli katkılar sağlayacağı düşünülmektedir.

Üniversite öğrencilerinin Kırgızistan'ın kültürel miras unsurlarına ilişkin bilinirlik ve deneyimleme algıları bağlamında farkındalığının geliştirilmesine yönelik çalışmalar teşvik edilmelidir. Kültürel mirasların gelecek kuşaklara aktarılmasında günümüz gençleri olan üniversite öğrencilerinin önemli bir misyon üstlendikleri unutulmamalıdır. Çalışmanın bulguları doğrultusunda kültürel miras unsurlarının bilinirlik ve deneyimleme düzeylerinin artırılarak farkındalığın sağlanmasına yönelik öneriler aşağıda maddeler halinde sıralanmıştır.

1. Kültürel miras unsurlarının genel olarak bilinirlik düzeylerinin yüksek deneyimleme düzeyleri düşük olduğu için toplumun her kesimine yönelik çeşitli etkinlikler (Festival, yarışma vb.) ile kültürel miras unsurlarını tanıma ve yerinde deneyimleme firsatları sağlanmalıdır.

2. Eğitim kurumlarının her kademesinde okuyan öğrencilere yönelik "Kültürel Miras" temalı derslere müfredatta yer verilmelidir. Böylece bilinç düzeyinin erken yaşlarda gelişimi sağlanabilecektir. Ayrıca, deneyimlerini artırmak için gezi organizasyonları yapılmalıdır. 
3. Kültürel miras unsurlarına ilişkin bilgilendirici çeşitli toplantı (Kongre, konferans, sempozyum, çalıştay, seminer vb.) organizasyonları düzenlenmelidir.

4. Kültürel miras unsurlarına ilişkin belgesel filmler çekilerek hem gelecek kuşaklara aktarılmasına hem de ülke tanıtımına destek olunmalıdır.

5. Devletin ülkenin kültürel miras değerlerine sahip çıkarak korunmasına yönelik politikalar belirlemesi gerekmektedir.

6. Tur operatörleri başta olmak üzere tüm turizm işletmeleri Kırgızistan'a gelen turistlere yönelik kültürel miras unsurlarını kapsayıcı tur paketleri ile broşür, katalog vb. tanıtım materyalleri hazırlatıp dağıtarak tanıtıma katkıda bulunmalıdırlar.

$\mathrm{Bu}$ çalışma, Bişkek'te ve KTMU öğrencilerine yönelik yapıldığı için genellenemez. Toplumun farklı kesimlerine yönelik benzer bir çalışma yapıldığı takdirde ilk defa bu çalışmada kullanılan Bilinirlik-Deneyimleme Analizi (BDA) ile karşılaştırma firsatı oluşacaktır. Ayrıca Kırgızistan'ın farklı bölge ve şehirlerinde benzer çalışmaların yapılması araştırmacılara önerilmektedir. Kültürel miras unsurlarına ilişkin bilinirlik-deneyimleme düzeyleri demografik değişkenler açısından da karşılaştırılarak toplumun farkındalık düzeyleri incelenebilir.

\section{KAYNAKÇA}

Ablak, S., Dikmenli, Y., \& Çetin, T. (2014). Üniversite öğrencilerinin Kırşehir'in tarihi ve kültürel turizm değerlerine yönelik farkındalıkları. Uşak Üniversitesi Sosyal Bilimler Dergisi, 7(2). 171-186.

Akay, A. S. (2006). Somut olmayan kültürel mirasın tarih araştırmalarında kaynak olma özelliği. Milli Folklor Dergisi, 18(70), 38-58.

Akkuş, G., Karaca, Ş. \& Polat, G. (2015). Miras farkındalığı ve deneyimi: üniversite öğrencilerine yönelik keşifsel bir çalışma. Akademik Baklş Uluslararası Hakemli Sosyal Bilimler Dergisi, (50), 71-81.

Akpirinç, E. \& Mancı, A. R. (2019). Yerel halkın kültürel miras farkındalığı ve deneyimi: Şanlıurfa örneği. Uluslararası Güncel Turizm Araştırmaları Dergisi, 3(2), 245-260. Doi:10.30625/ijctr.647631.

Albayrak, T. \& Caber, M. (2011). Importance-Performance Analysis: A Sample About Destination Management. Ege Academic Review, 11(4), 625-636.

Avcıkurt, C. (2007). Turizm sosyolojisi; turist-yerel halk etkileşimi. Ankara: Detay Yayınları

Besculides, A., Lee, M. E. \& McCormick, P. J. (2002). Residents' perceptions of the cultural benefits of tourism. Annals of Tourism Research, 29(2), 303-319. Doi: 10.1016/S0160-7383(01)00066-4.

Breakey, N. M. (2012). Studying world heritage visitors: the case of the remote riversleigh fossil site, Visitor Studies, 15(1), 82-97.

Buluk, B. (2017). Cultural heritage awareness of tourism undergraduate students: the case of Çanakkale Onsekiz Mart University. International Congress of Tourism and Cultural Heritage, Muğla.

Can, M. (2009). Kültürel Miras ve Müzecilik Çalışma Raporu. Ankara. https://teftis.ktb.gov.tr/Eklenti/1279, muserrefcanpdf.pdf?0, Erişim tarihi: 25.06.2020.

Carbone, F., Oosterbeek, L., \& Costa, C. (2012). The educational and awareness purposes of the Paideia approach for heritage management. Natural Hazards and Earth System Science, 12, 1983-1986. http://dx.doi.org/10.5194/nhess-12-1983-2012.

Correia, A., Kozak, M. \& Ferradeira, J. (2013). From tourist motivations to tourist satisfaction. International Journal of Culture, Tourism and Hospitality Research, 7(4), 411-424. Doi:10.1108/IJCTHR-052012-0022. 
Coşkun, R., Altunışık, R., Bayraktaroğlu, S., \& Yıldırım, E. (2015). Araştırma yöntemleri, Sakarya: Sakarya Yayıncilik.

Çetin, T. (2010). Cumalıkızık köyünde kültürel miras ve turizm algısı. Milli Folklor Dergisi, 22(87):181-190.

Göğebakan, Y. (2015). Dünya üzerindeki kültürel varlıkların turizme ve ekonomiye katkısı. Anadolu Üniversitesi Sanat ve Tasartm Dergisi, 5(2), 48-71.

Güneş, E. \& Alagöz, G. (2018). Turizm eğitimi alan öğrencilerin kültürel miras tutumları üzerine bir araştırma. Adlyaman Üniversitesi Sosyal Bilimler Enstitüsü Dergisi, (29), 753-777. Doi: 10.14520/adyusbd.397551.

Halaç, H., Mokrane, H. \& Turan, S. (2019). TÖMER öğrencilerinin kültürel miras ve koruma farkındalığı; Eskişehir Anadolu Üniversitesi örneklemi. Journal of Awareness, 4 (2), 185-204. Doi: 10.26809/joa.4.015.

İnce C. \& Samatova, G. (2018). Gastronomi Turizmi Kapsamında Yaşayan Kırgız Mutfağının Farkındalık Düzeyi: Üniversite Öğrencileri Örneği. Journal of Tourism and Gastronomy Studies, 6(2), 369386. Doi: $10.21325 /$ jotags.2018.219.

Jokilehto, J. (2005). Definition of cultural heritage: references to documents in history. ICCROM Working Group 'Heritage and Society, 4-8.

Karaca, Ş., Akkuş, G., Şahbudak, E. \& Işkın, M., (2016). A study of awareness of cultural heritage Sivas sample. International Journal of Humanities and Social Science Invention (IJHSSI), 5(9), 73-81.

Karadeniz, C. B. (2020). Assessment for awareness and perception of the cultural heritage of geography students. Review of International Geographical Education (RIGEO), 10 (1), Special Issue, 40-64. Doi: 10.33403 rigeo.640722.

Keçe, M. (2015). Sosyal bilgiler öğretmen adaylarının Ankara'nın tarihi ve kültürel turizm değerlerine yönelik ilgi ve farkındalıkları. Journal of Kirsehir Education Faculty, 16(1), 131-149.

Kocadaş, B. (2005). Kültür ve medya. Bilig, (34), 1-13.

Kozak, N., Kozak, M.A. \& Kozak, M. (2011). Genel turizm (ilkeler-kavramlar). Ankara: Detay Yayıncılık.

Mancı, A. R. (2019). Üniversite öğrencilerinin kültürel miras farkındalığı ve deneyimleri: Harran Üniversitesi örneği-Şanlıurfa. Türk Turizm Araştırmaları Dergisi, 3(4), 1164-1177.

Martilla, J. A. \& James, J. C. (1977). “Importance-performance analysis”, Journal of Marketing, 41(1), 77-79.

Nguyen, T.H.H. \& Cheung, C. (2014). The classification of heritage visitors: A case of Hue City, Vietnam. Journal of Heritage Tourism, 9 (1), 35-50.

Okuyucu, A., \& Somuncu, M. (2012). Kültürel mirasın korunması ve turizm amaçlı kullanılmasında yerel halkın alg1 ve tutumlarının belirlenmesi: Osmaneli ilçe merkezi örneği. Ankara Üniversitesi Çevrebilimleri Dergisi, 4(1), 37-51.

Öztürk, A. \& Caber, M. (2017). Kültürel miras ve üniversitelerin turizm rehberliği bölümlerinde (lisans/önlisans) kültürel miras eğitimi üzerine bir durum tespiti, Avrasya Sosyal Bilimler Akademisi Sosyal Bilimler Dergisi, Özel Sayı.

Santa-Cruz, F. G., \& López-Guzmán, T. (2017). Culture, tourism and world heritage sites. Tourism Management Perspectives, 24, 111-116.

Saruhan, Ş. C., \& Özdemirci, A. (2011). Bilim, felsefe ve metodoloji. İstanbul: Beta.

Shankar, B., \& Swamy, C. (2013). Creating awareness for heritage conservation in the city of Mysore: Issues and policies. International Journal of Modern Engineering Research (IJMER), 3, 698-703. 
Srivastava, S. (2015). A study of awareness of cultural heritage among the teachers at university level. Universal Journal of Educational Research, 3(5), 336-344. Doi: 10.13189/ujer.2015.030505.

Su, M. M. \& Wall, G. (2011) Chinese Research on World Heritage Tourism, Asia Pacific Journal of Tourism Research, 16:1, 75-88, Doi: 10.1080/10941665.2011.539392.

Sürücü, O. \& Başar, M. E. (2016). Kültürel mirası korumada bir farkındalık aracı olarak sanal gerçeklik. Artium, 4(1), 13-26.

Tabachnick, B.G. \& Fidell, L.S. (2013). Using multivariate statistics (sixth ed.). Boston: Pearson.

Tekeli, İ. (2010). Gündelik yaşam, yaşam kalitesi ve yerellik yazıları, İstanbul: Tarih Vakfi Yurt Yayınları.

Tetik, N. (2012). Turist rehberlerinin ekoturizm alanındaki yeterliliklerinin önem-performans analizi. Seyahat ve Otel İsletmeciliği Dergisi, 9(3), 6-24.

Tören, E., Kozak, N. \& Demiral, G. N. (2012). Eskişehir'in kültürel miras varlıklarının korunmasında kamu kurumlarının rolü. Aksaray Üniversitesi İ̈BF Dergisi, 4(2), 69-88.

UNESCO (2005). Basic Texts of the 1972 World Heritage Convention. http://whc.unesco.org/uploads/activities/documents/activity-562-4.pdf. Erişim tarihi: 25.06.2020.

UNESCO (2020). Elements on the Lists of Intangible Cultural Heritage. https://ich.unesco.org/en/state/kyrgyzstan-KG?info=elements-on-the-lists. Erişim tarihi: 25.06.2020.

Uslu, A., \& Kiper, T. (2006). Turizmin kültürel miras üzerine etkileri: Beypazarı/Ankara örneğinde yerel halkın farkındalığı. Tekirdă̆ Ziraat Fakültesi Dergisi, 3(3), 305-314.

Usta, N. (2012). İnanç turizminden kültür turizmine: Midilli Adası'nın Agiasos dağ köyü örneği, KMÜ Sosyal ve Ekonomik Araştırmalar Dergisi, 14 (22): 163-168.

Vecco, M. (2010). A definition of cultural heritage: from the tangible to the intangible. Journal of Cultural Heritage, 11(3), 321-324.

Yang, C.C. (2003). Improvement actions based on the customers' satisfaction survey, Total Quality Management \& Business Excellence, 14(8), 919-930, Doi:10.1080/1478336032000090842. 